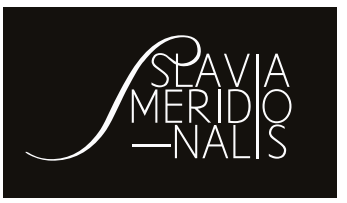

\title{
Ана Стойкова
}

Институт за литература

Българска академия на науките

\section{За възможните източници на апокрифния мотив „Сатанаил отказва да се поклони на Адам“ в едно раннохристиянско мъчение}

Някои от най-популярните старозаветни апокрифи са свързани с появата на злото начало - Сатаната, в човешката история. Част от най-ранните митологични представи на човечеството, разказите за разбунтувалия се и низвергнат от Бога ангел отдавна са предмет на научни изследвания както в еврейската и византийската, така и в старите славянски литератури ${ }^{1}$. Особен интерес представлява въпросът за тяхното широко разпространение през раннохристиянската епоха и проникването им в жанрове, които се отнасят към „високата“ и дори към богослужебната литература. Така дори след приемането на канона редица текстове, които не попадат в него и по-късно се смятат за апокрифи, продължават да бъдат много популярни и да оказват

1 От значителната литература върху мотива за падането на ангела ще спомена само: Порфирьев (1872); Gaylord (1982); Димитрова (1986); Anderson (2000, с. 99-102); Stone (2000, с. 45-48); Badalanova Geller (2011); Димитрова (2014, с. 37-50).

This work was supported by the Bulgarian Academy of Sciences.

Competing interests: no competing interests have been declared.

Publisher: Institute of Slavic Studies, PAS.

This is an Open Access article distributed under the terms of the Creative Commons Attribution 3.0 PL License (creativecommons.org/licenses/by/3.0/pl/), which permits redistribution, commercial and non-commercial, provided that the article is properly cited. (c) The Author(s) 2016. 
голямо влияние, наравно с каноничните текстове, при формирането на ранните агиографски произведения. При работата ми върху най-ранното анонимно дометафрастово Мъчение на св. Георги, възникнало още към края на IV в. и преведено на старобългарски не по-късно от X в., попаднах на апокрифния мотив „Сатанаил отказва да се поклони на Адам“. Този мотив е част от по-големия наратив за „първия сред ангелите“, който заради непокорството си е отхвърлен от Божието царство и се превръща във враг на Бога и хората. В различните произведения, които го съдържат (Димитрова, 1986, с. 27-28), се срещат различни мотиви на конкретната причина върховният ангел да бъде низвергнат. В своето изследване Д. Димитрова посочва седем варианта на причината, между които „Замисъл на един от ангелите да постави престола си над облаците“, „Кражба на семена по време на саденето на Рая“, „Бунтуване на ангелите и намаляване на данъците“, „Кражба на символите на божествената власт“ и др. (Димитрова, 1986, с. 29-30). Мотивът, който е използван в Мбчението на св. Георги - „Сатанаил отказва да се поклони на Адам“, е отбелязан от Димитрова като 1.Г и е анализиран накратко (Димитрова, 1986, с. 28, № 20, 34-35). Тук ще се опитам да потьрся някои от паралелите на мотива от Мъчението и възможните му източници както в славянската, така и в по-ранните литературни традиции на Византия и Близкия изток.

В един от епизодите на ранното Мбчение, запазено в три славянски редакции (Стойкова, Христова-Шомова, Малчев, \& Рангочев, 2012), се разказва как св. Георги изгонва от езическия храм демона (нечистия дух, беса), обитаващ статуята на Аполон, и разрушава идолите. Мъченикът принуждава демона да се покаже в истинския си вид, като изпраща в храма едно невръстно дете, което да го повика. Поради немощта си да се противопостави на невинното дете, демонът с нежелание се покорява и разказва своята история:

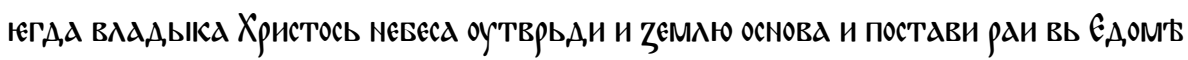
НА ВЬСТОЦ', И СТВОРН ЧАОВ'ВКА ПРЬСТЬ ВЬZЬМЬ ОТЬ ZЕМАК, ТОГАА ЖЕ ГААГОАА КЬ

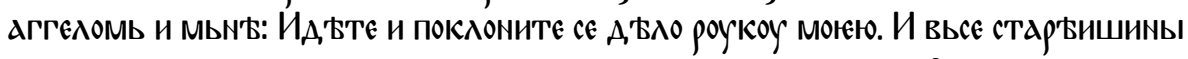

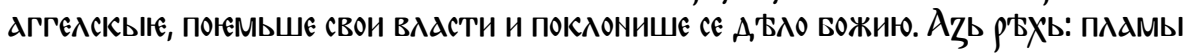

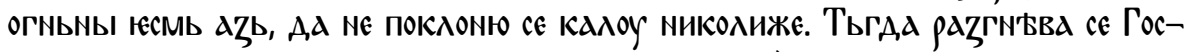

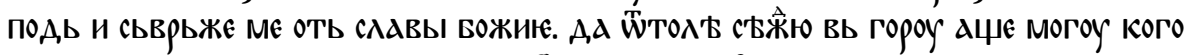

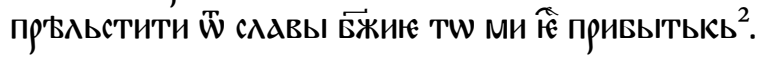

2 Текстът се цитира по преписите НББ 464 (Народна библиотека, Белград, изгорял през Втората световна война; изд. Novaković, 1876) и Дечани 95 (Народна библиотека на Сърбия, 
Разказът на демона за това, че отказал да се поклони на първия човек и затова бил низвергнат, е налице в първите две от трите славянски редакции на Мъчението. Частично е запазен и в две от гръцките версии на ранното Мбчение (Athen и Paris; Krumbacher, 1911, с. 3-16, 18-30, 109-126, 138-147) - там демонът признава, че е бил низвергнат от Бога, но не споменава причината за това. Веднага след като разказва за създаването на Небето, Земята и Рая, той съобщава, че Бог му се разсърдил и го хвърлил на земята, където пребивава досега:

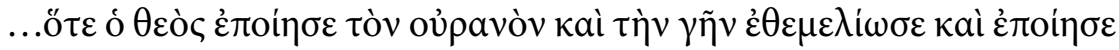

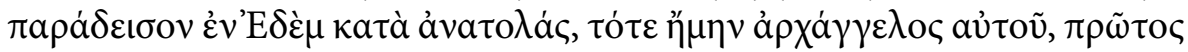

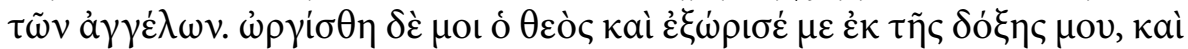

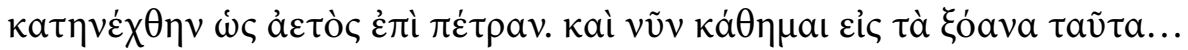
(Krumbacher, 1911, c. 12-13) ${ }^{3}$.

Мотивът за отказа на демона да се поклони на човека обаче се среща в три други чуждоезични версии на Мбчението на св. Георги - в една от двете латински (Gall) (Arndt, 1874, с. 65), в коптската (Kopt) (Wallis Budge, 1888 , с. 229-230) ${ }^{4}$ и в етиопската (Ethiop) (Wallis Budge, 1930, с. 101) . $^{5}$ На таблицата се вижда сравнението между тях и славянския текст:

Белград, сбирка на Дечанския манастир № 95). Новобълг. превод: „Когато владиката Господ утвърди небесата и земята основа и Рая насади на Изток в Едем и направи човека, като взе пръст от земята, тогава каза на нас, своите ангели: „Идете и се поклонете на делото на моята ръка!“. И дойдоха архангелите и цялото ангелско войнство и се поклониха на Божието дело. Аз рекох: „Огнен пламък съм и никога няма да се поклоня на направеното от кал!”. Тогава Господ се разгневи и ме отхвърли от славата си. И оттогава седя в планината и ако мога да прелъстя някого, това ми е печалбата“ (тук и нататък преводът на новобълг. език е мой - А. С.).

3 „...защото Бог създаде небето и основа земята и направи рая в Едем на Изток, тогава бях негов архангел, първи сред ангелите. Разсърди ми се Бог и ме прогони от славата ми и паднах като орел на камък, и сега седя в този истукан....”.

4 „И той започна да говори [...] казвайки: О, господарю и Боже свети, ти не може да не знаеш, че в старите времена Бог направи рая в Едем, на изток, и че Бог постави в него човека, когото направи по свой образ. И Бог каза: „Нека ангелите дойдат и му се поклонят"; и веднага Михаил и цялата му армия от ангели дойдоха и му се поклониха. Но аз не бих се поклонил на човека, когото Бог сътвори, и оспорих заповедта на Бога, като казах: „О, праведни съдия, когото засланя изпълненият с очи херувим, как може аз, който съм по-съвършен от този човек, да почета това, което е по-долно от мене?” Тогава Бог ми се разгневи много и ме отхвърли от славата, с която бях заобиколен, и той ме отхвърли от небесата като орел върху камък и аз бях в окови; и сега живея в този идол и отклонявам от правия път децата на човека”.

5 „Тогава Сатаната започна да говори и извика спомена за деня на своята злочестина и как Бог сътвори небесата и постави земята и посади градина в нея 


\begin{tabular}{|c|c|c|c|}
\hline Gall & Kopt & Ethiop & Slav (НББ464) \\
\hline $\begin{array}{l}\text { Respondit ei idolum: } \\
\text { quando deus caelum } \\
\text { cameravit et terram } \\
\text { fundavit, paradisum } \\
\text { contra orientem } \\
\text { Eden, dixit deus: } \\
\text { facia mus homi- } \\
\text { nem ad imaginem } \\
\text { et similitudinem } \\
\text { nostram. Et descen- } \\
\text { dit in paradisum, } \\
\text { et accipiens limum } \\
\text { terrae, et plasmavit } \\
\text { hominem et dixit } \\
\text { nobis angelis: }\end{array}$ & $\begin{array}{l}\text { And he began to } \\
\text { speak [...] saying: } \\
\text { O master and saint } \\
\text { of God, thou art } \\
\text { not ignorant that of } \\
\text { old time God made } \\
\text { a paradise in Eden, } \\
\text { towards the east, } \\
\text { and that God put in } \\
\text { it the man He had } \\
\text { made in His own } \\
\text { likeness. And God } \\
\text { said, }\end{array}$ & $\begin{array}{l}\text { Then Satan began to } \\
\text { speak, and he called } \\
\text { to remembrance the } \\
\text { day of his tribula- } \\
\text { tion, and how God } \\
\text { made the heavens, } \\
\text { and established the } \\
\text { earth, and planted } \\
\text { a garden therein, } \\
\text { and how he turned } \\
\text { towards the East } \\
\text { and took thought } \\
\text { and said, "Let us } \\
\text { make man in our } \\
\text { form and likeness." } \\
\text { And how straight- } \\
\text { way He went down } \\
\text { into the garden, and } \\
\text { fashioned man, and } \\
\text { how He took the } \\
\text { dust of the earth in } \\
\text { His hands, and how } \\
\text { having finished the } \\
\text { work He went up } \\
\text { and said unto His } \\
\text { angels, }\end{array}$ & 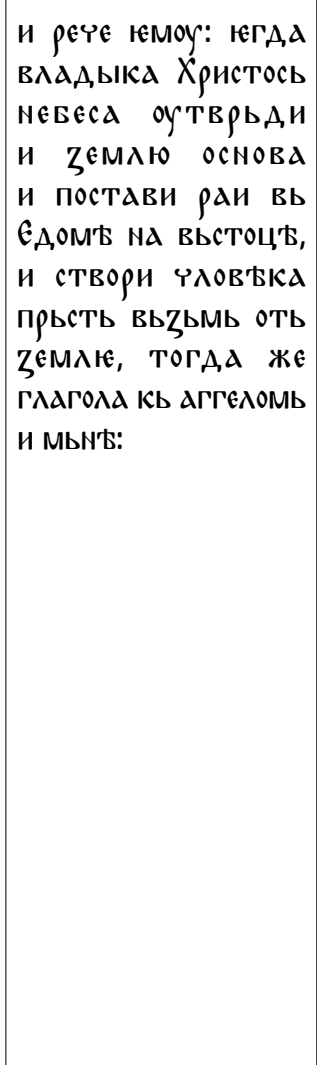 \\
\hline
\end{tabular}

и как се обърна на Изток и помисли и рече: „Нека да направим човек в нашия образ и подобие”. И как веднага Той слезе долу в градината и оформи човека и как взе прах от земята в ръцете Си и как, като завърши работата Си, се качи и каза на Своите ангели: „Вървете и отдайте почит на това, което направиха ръцете Ми”. И веднага Михаил стана и отдаде почит [на човека] както му беше заповядано. „И аз бях там и престъпих заповедта на справедливия Господ и Му казах: „Как мога да го почета, като знам, че го предхождам при неговото сътворение, и аз се скрих близо до серафима, та да не се поклоня на това, което е по-ниско от мене, и отказах да го направя". И Бог ми се разгневи и ме отхвърли от моето положение на слава и ме принуди да падна долу като дъжд върху скали. И аз станах по-долен от моите братя и Той ме постави на края на небето". 


\begin{tabular}{|c|c|c|c|}
\hline Gall & Kopt & Ethiop & Slav (НББ464) \\
\hline $\begin{array}{l}\text { venite adorare opera } \\
\text { manuum mearum. } \\
\text { Et continuo Michahel } \\
\text { angelus adoravit } \\
\text { opera manuum eius, } \\
\text { ego vero contradixi } \\
\text { domino deo: }\end{array}$ & $\begin{array}{l}\text { "Let the angels come } \\
\text { and worship him;“" } \\
\text { and stright way } \\
\text { Michael and all his } \\
\text { army of angels came } \\
\text { and worshipped } \\
\text { him. But I would } \\
\text { not worship the man } \\
\text { whom God had cre- } \\
\text { ated, and I disputed } \\
\text { the command of } \\
\text { God, saying: }\end{array}$ & $\begin{array}{l}\text { "Go ye and do } \\
\text { homage to that } \\
\text { which My hands } \\
\text { have made." And } \\
\text { strightway Michael } \\
\text { rose up and did } \\
\text { homage [to man] } \\
\text { according to the } \\
\text { command. "And } \\
\text { I was there, and } \\
\text { I transgressed the } \\
\text { command of the } \\
\text { righteous Governor, } \\
\text { and I said unto Him, }\end{array}$ & 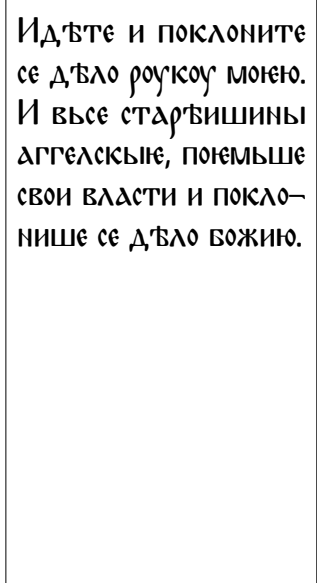 \\
\hline $\begin{array}{l}\text { quid est quod ego } \\
\text { unum obumbrabam } \\
\text { sub pennas Cheru- } \\
\text { bin et nunc adorabo } \\
\text { inferiorem meum? } \\
\text { Non facio hoc. }\end{array}$ & $\begin{array}{l}\text { "O rightous judge, } \\
\text { whom the Cheru- } \\
\text { bim full of eyes } \\
\text { overshadow, how } \\
\text { can I who am more } \\
\text { excellent than this } \\
\text { man, worship that } \\
\text { which is inferior to } \\
\text { me?" }\end{array}$ & $\begin{array}{l}\text { How can I do homage } \\
\text { to him seeing that } \\
\text { I preceded him in } \\
\text { his creation, and I hid } \\
\text { myself in the region } \\
\text { below the Seraphim } \\
\text { so that I might not } \\
\text { do homage to him } \\
\text { that was inferior to } \\
\text { me, and I refused to } \\
\text { do this. }\end{array}$ & 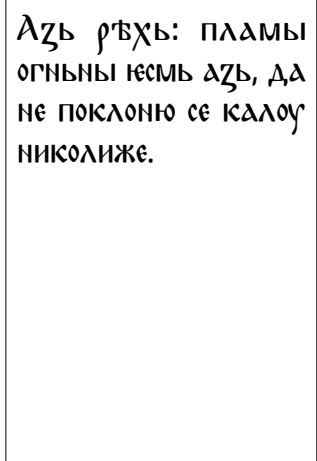 \\
\hline $\begin{array}{l}\text { Et iratus est mihi } \\
\text { dominus et abstulit } \\
\text { a me gloriam meam, } \\
\text { et proiecit me ut plu- } \\
\text { viam super terram, } \\
\text { et factus sum mini- } \\
\text { mus omnibus cre- } \\
\text { aturis. Et nunc } \\
\text { permaneo super } \\
\text { statuas casuras, et } \\
\text { si potuero aliquem } \\
\text { inducere, ipsum est } \\
\text { mihi lucrum. }\end{array}$ & $\begin{array}{l}\text { Then God was very } \\
\text { wroth with me, and } \\
\text { he cast me forth } \\
\text { from the glory with } \\
\text { which I was sur- } \\
\text { rounded, and He } \\
\text { cast me forth from } \\
\text { heaven like an eagle } \\
\text { on a rock, and I was } \\
\text { in fetters; and now } \\
\text { I live in this idol, } \\
\text { and I lead astray the } \\
\text { children of men. }\end{array}$ & $\begin{array}{l}\text { And God was wroth } \\
\text { with me, and He } \\
\text { drove me forth from } \\
\text { my state of glory, } \\
\text { and He made me to } \\
\text { come down like rain } \\
\text { among rocks. And } \\
\text { I became inferior } \\
\text { to my brethren, and } \\
\text { He placed me in the } \\
\text { edge of the heaven. }\end{array}$ & 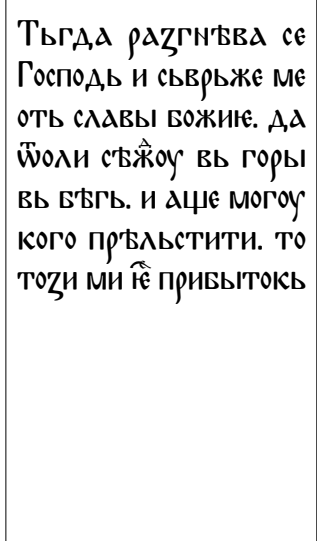 \\
\hline
\end{tabular}


Сравнението показва, че в чуждоезичните версии разказът на демона е предаден по-пространно, особено в етиопската. Независимо от това обаче се вижда, че в тях причините за отказа на демона да се поклони са сходни - той изтъква по-високото си положение по отношение на създадения от Бога човек. Според латинския текст демонът е този, който „е единственият закрилян от сянката на крилете на херувимите“ - пазачите на Дървото на живота (Бит. 3: 24), и не може да се поклони на по-нискостоящ от себе си: „Защото мене покриват крилете на херувимите, как да се поклоня на стоящия по-ниско от мене? Няма да го направя!“ В коптската версия демонът също недоумява как може той, превъзхождащият човека, да се поклони на по-долния от него; тук също се споменава херувим, но като част от обръщението към Бога, пазен от покритите с очи небесни създания: „О праведни съдия, когото засланя изпълненият с очи херувим, как може аз, който съм по-съвършен от този човек, да почета това, което е по-долно от мене?“. В етиопската версия пък демонът не иска да се поклони на Адам, защото при Сътворението човекът е създаден след него, следователно е по-нисш; за да не изпълни заповедта, той се скрива в място, намиращо се под серафимите, огнените шесткрили същества, летящи край трона на Бога (Ис. 6: 1-8.): „Как мога да го почета, като знам, че го предхождам при неговото сътворение, и аз се скрих близо до серафима, та да не се поклоня на това, което е по-ниско от мене, и отказах да го направя“. Единствено в славянските версии се среща като причина за нежеланието на демона, който тук нарича себе си „огнен пламък“, да се поклони на Адам, това, че той е създание, направено от кал: Аұь р'ъүь: пламы огньмы

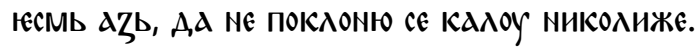

Демонът в славянския текст на Мъчението, с когото Георги разговаря пред езическия храм, не е назован по име. Мъченикът изпраща детето да повика Аполон, бога, на когото се покланят Диоклетиан и езичниците, и тогава от истукана излиза нечистият или дяволски

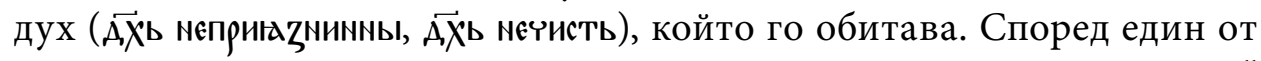
гръцките текстове, които съдържат този мотив, „духът от истукана“ разказва, че по време на Сътворението той е бил Божият архангел, „Първият сред ангелите“, т.е. Сатанаил; в етиопската версия той е назован направо „Сатана“. Всъщност и названието „огнен пламък“, което демонът употребява за себе си в славянските преписи, също отпраща към Сатанаил, падналия като светкавица от небето ангел, за когото се 
споменава у Лука, гл. 10: 17-18 $8^{6}$ Очевидно е, че мотивът за падналия ангел, който се крие в статуята на Аполон, е общ за цялата традиция на Мъчението на св. Георги и вероятно се отнася към първоначалния му текст. Славянските редакции на творбата обаче пазят специфичния само за тях вариант, който обяснява нежеланието на Сатанаил да се поклони на Човека с противопоставянето „огнен пламък - кал“.

На какво може да се дължи тази особеност на славянската традиция? Дали тя пази някакво четене от неизвестна днес гръцка редакция, или пък може да се предположи, че става дума за интерполация, направена на славянска почва? Като основание за подобна хипотеза би могъл да послужи фактът, че разглежданият мотив за нежеланието на Сатанаил да се поклони на Адам има преки паралели в редица славянски старозаветни апокрифи (вж. Димитрова, 1986, с. 27-28 и посочената там литература). Той се среща в различни съчинения - в Тивериадското море (налице е преди всичко в някои негови руски преписи) (Иванов, 1925, с. 287-311; Димитрова, 2014, с. 180-181), в славянския превод на Откровение на Варух (3 Варух) (Тихонравов, 1894, с. 48-54; Иванов, 1925, c. 191-207; Kulik, 2010, с. 189), в Прение на Антихрист с Господа наш Исус Христос (Иванов, 1925, с. 248-257) и в Слово за лъжливия Антихрист, безбонния Сатанаил, как го плени архангел Михаил, войвода на всички ангели (Петканова, 1981, с. 41) ${ }^{7}$, а отгласи и реминисценции от него могат да се намерят и в други апокрифни творби. Единствено в Откровение на Варух обаче, също както в Мъчението на св. Георги, Сатанаил изтъква като причина за непокорството си превъзходството на своята огнена същност над направения от пръст Адам, докато в останалите произведения тя не е посочена. Не може да се каже, че текстовете в някоя от тези творби или в Мбчението на св. Георги, са заимствани един от друг - те са твърде различни не само като език и стил, но и мотивът е поставен в различна фабулна ситуация. Едно сравнение между техните текстове веднага подчертава различията.

6 Лк. 10: 17. Седемдесетте ученици се върнаха с радост и казваха: Господи, в Твое име и бесовете се покоряват нам. 18. А Той им рече: видях сатаната, как падна от небето като светкавица.

7 „Сатанаил видя тогози човек, падна ничком на земята, обладан от зла мисъл, и си рече: „Господ създаде от земна пръст човека и го постави над всички, вишният отец го прослави, а ангелските сили му се покланят. Аз не мога да го гледам, нито да му се поклоня“. 
Ана Стойкова

\begin{tabular}{|c|c|c|c|}
\hline $\begin{array}{c}\text { Мъчение на } \\
\text { св. Георги } \\
\text { (НББ464) }\end{array}$ & $\begin{array}{l}\text { Тивериадското море } \\
\text { (Иванов, 1925, с. 297) }\end{array}$ & $\begin{array}{c}\text { Откровение на Варух } \\
\text { (Тихонравов, } 1894, \\
\text { с. } 50)\end{array}$ & $\begin{array}{c}\text { Прение на Антихрист } \\
\text { с Исус Христос } \\
\text { (Иванов, 1925, с. } 251)\end{array}$ \\
\hline 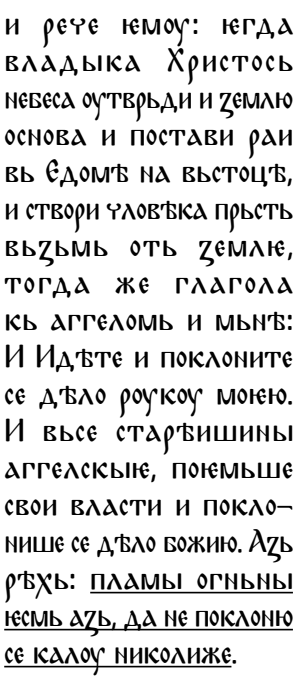 & $\begin{array}{l}\text { И рече господь } \\
\text { сатанъ: поклонис ты } \\
\text { Адаму! } \\
\text { И рече сатана: } \\
\text { я твоему созданию } \\
\text { не поклонюся. } \\
\text { И рече Гдс сатанъ: } \\
\text { окаяныи дияво } \\
\text { лстивыи сатана! }\end{array}$ & 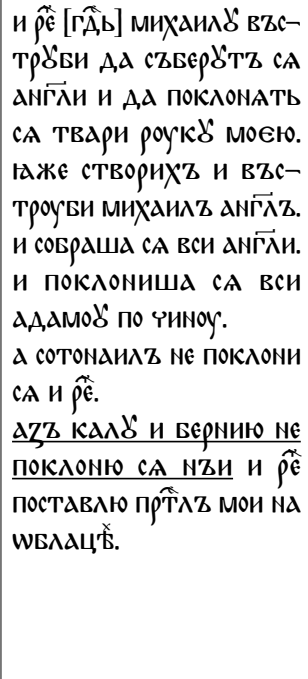 & 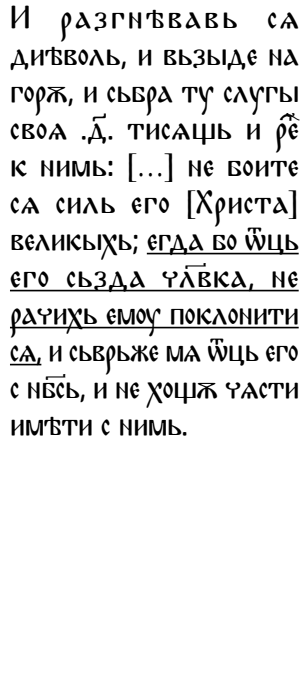 \\
\hline
\end{tabular}

Мотивът за отказа на Сатанаил да се поклони на Адам е налице и в редица други съчинения, непреведени или несъхранени в славянски преписи. Макар че не се среща в гръцката и в славянската редакция на Слово за Адам и Ева например, мотивът е налице в неговата латинска, арменска и грузинска версия, засвидетелстван е също в сирийската книга с новозаветни апокрифи Пещера на съкровищата (The Book of the Cave of Treasures, 1927, с. 55-56), както и в Корана (сура 2:32, 15:26-39, 17:36) (Badalanova Geller, 2011, c. 83). Разпространението му в толкова много на брой различни произведения свидетелства за вероятното съществуване на някакъв апокрифен пра-текст, към който възхождат (през повече или по-малко посредници) всички тези творби. Смята се, че две от цитираните съчинения - Тивериадското море и Прението на Антихрист с Исус $X p u c т о с$, са славянски компилации, създадени въз основа на други, вече преведени апокрифи, някои от които са съдържали разглеждания мотив (Димитрова, 2014, с. 90). Мъчението на св. Георги обаче е възникнало значително по-рано от тях, към края на IV в., приблизително по едно и също време със Слово за Адам и Ева, което се датира между началото на III 
и V в. (Johnson, 1985), и малко след Откровение на Варух, за чието време на възникване се приема краят на I - началото на II в. сл. Xp. (Gaylord, 1983, с. 655-656). Тези две творби са староеврейски псевдоепиграфи, които също са черпали от общ източник, при това общ вероятно не само за тях, но и за други съчинения от тази епоха. Едно такова съчинение е Слово за Авадон от александрийския патриарх Тимотей (380-385), коптско раннохристиянско съчинение, за което се смята, че е преписано от по-стар сборник, намерен от патриарха в библиотеката на апостолите в Йерусалим (Wallis Budge, 1914). В Словото се съдържа разказ на Исус Христос за сътворението на човека като отговор на въпроса на апостолите защо Бог е направил ангела на смъртта, Авадон, цар на всички хора'. Там се съдържа друг вариант на мотива за отказа на сатаната да се поклони на Адам:

...And the man lived straightway, and became a living soul, according to the image and likeness of God. [...] Thereupon My Father set him upon a great throne, and He placed on his head a crown of glory, and He put a royal sceptre [in his hand], and My father made every order [of angels] in the heavens to come and worship him, whether angel or archangel. And all the hosts of heaven worshipped God first of all, and then they worshipped Adam, saying, „Hail, thou image and likeness of God“. And He intended that the order of the angels who were fashioned [before Adam] should worship him, and My Father said unto him (i.e. their chief), „Come, thou thyself shalt worship my image and likeness". And he, a being of great pride, drew himself up in a shameless manner, and said, „It is meet that this [man Adam] should come and worship me, for I existed before he came into being".

And when My Father saw his great pride, and that his wickedness and his evil-doing were complete, He commanded all the armies of heaven,

8 Авадон (Аватон) е ангел на смъртта от еврейската Библия; в Откровението на Йоан (9:11) той е наречен „ангел на бездната” и е даден гръцкият превод на името му:

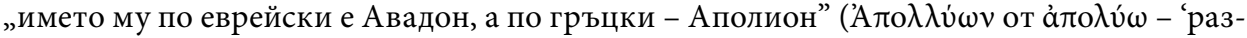
рушавам'). В някои коментари името Аполион се извежда от името на древногръцкия бог Аполон, но, макар в случая с разглеждания мотив от Мъчението да става дума за демона, скрит в статуята на Аполон, е погрешно да се прави такава връзка.

9 Литературната форма на Словото, която представлява беседа на Спасителя с неговите ученици, напомня композицията на Тайната книга на богомилите. Отговаряйки на въпросите на апостолите, Христос разказва пред тях историята на Авадон и съдбата му, разкрива своето участие в деня на Страшния съд, предсказва възнесението на Йоан и оповестява как ще спаси праведните и ще накаже грешните. 
saying, [...] to a mighty Cherubim, and he smote him, and cast him down from heaven upon the earth, because of his pride, and he broke his wings and his ribs and made him helpless... (Wallis Budge, 1914, c. 483-484) ${ }^{10}$.

В Слово за Авадон като че ли се открива източникът на мотива в архетипния текст на Мъчението на св. Георги - тук са налице и нежеланието на Сатанаил да се поклони, защото е създаден преди човека, и херувимът, който поразява горделивия ангел и го хвърля от небето на земята - елементите, които са налице в латинската и ориенталските (коптската и етиопската) версии на текста му.

Интерес представлява също и друго вече споменато съчинение, което съдържа този мотив - Пещерата на съкровищата, приписвано на Ефрем Сирин (ок. 306-373), но вероятно възникнало по-късно, през VI в., въз основа на по-стари източници. Книгата има за цел да придаде на християнската история космически измерения и да представи Христос като наследник на Адам. В нея също се разказва за низвержението на Сатанаил и се описва как той отказва да се поклони на Човека. Думите му са доста близки до запазения в славянските редакции на Мъчението текст, макар че контекстът е различен, а причината за падането му от небето - съвсем друга:

And the angels and the hosts of heaven heard the Voice of God saying unto him [Adam], „Adam, behold; I have made thee king, and priest, and prophet, and lord, and head, and governor of everything which hath been made and created; and they shall be in subjection unto thee, and they shall be thine, and I have given unto thee power over everything which I have created“. And when the angels heard this speech they all bowed the knee and worshipped Him.

10 Бълг. превод: „...И човекът оживя и стана жива душа по Божий образ и подобие. И моят Отец го сложи на голям трон, постави на главата му короната на славата и му връчи царски скиптър и нареди всеки ангелски чин да дойде и да му се поклони ... И всички небесни обитатели се поклониха първо на Бога и след това на Адам, казвайки: „Привет, ти Божий образ и подобие!”. И той нареди и онези ангели, създадени преди Адам, да му се поклонят и каза на главния сред тях: „Ела, ти също трябва да се поклониш на моя образ и подобие!”. А той, поради голямата си гордост, се дръпна безсрамно и каза: „Подобаващо е този човек да дойде и да ми се поклони, защото аз съществувах преди той да бъде създаден!". И когато баща ми видя неговата гордост и че беше изпълнен със злина, заповяда на небесното си войнство, като каза ... на могъщия херувим и той го порази и го хвърли от небето на земята, заради гордостта му, и счупи крилата му и ребрата му и го направи безпомощен...” 
And when the prince of the lower order of angels saw what great majesty had been given unto Adam, he was jealous of him from that day, and he did not wish to worship him. And he said unto his hosts, „Ye shall not worship him, and ye shall not praise him with the angels. It is meet that ye should worship me, because I am fire and spirit; and not that I should worship a thing of dust, which hath been fashioned of fine dust". And the Rebel meditating these things would not render obedience to God, and of his own free will he asserted his independence and separated himself from God. But he was swept away out of heaven and fell, and the fall of himself and of all his company from heaven took place on the Sixth Day, at the second hour of the day. And the apparel of their glorious state was stripped off them. And his name was called "Sâtânâ “ because he turned aside [from the right way], and "Shêdâ" because he was cast out, and „Daiwâ" because he lost the apparel of his glory. And behold, from that time until the present day, he and all his hosts have been stripped of their apparel, and they go naked and have horrible faces (The Book of the Cave of Treasures, 1927, c. 55-56) ${ }^{11}$.

Както се вижда, тук е налице близък паралел със славянските версии на Мъчението на св. Георги, където Сатаната нарича себе си „огнен пламък“ и не желае да се поклони на направения от „кал“Адам; очевидно е, че мотивът в тях има общ източник, който обаче е различен от онзи, отразен в латинската и ориенталските версии на Мъчението и в Слово за Авадон.

11 „И ангелите и небесното войнство чуха гласа на Бога, който му каза: Адаме, виж! Аз те направих цар, и свещеник, и пророк, и господар, и глава, и управител на всичко направено и създадено; и всичко трябва да ти бъде подчинено и всички ще са твои и ти давам власт над всичко, създадено от мене!”. И ангелите чуха словата му, всички те подвиха колене и му се поклониха. А когато князът на по-ниския ангелски чин видя, че на Адам е дадена велика почест, възревнува от този ден и не пожела да му се поклони. И каза на воините си: „Няма да му се поклоня и няма да го славя с ангелите. Редно е той да ми се поклони на мене, защото аз съм огън и дух; и не аз трябва да почитам нещо от прах, направено от ситен прах". И замислиха метеж да не се подчинят на Бога и по своята свободна воля той заяви своята самостоятелност и се отдели от Бога. Но беше пометен от небето и падна, и неговото падане и на неговите придружители стана на Шестия ден, във втория час на деня. И бяха съблечени от тях одеждите на техния божествен ранг. И неговото име беше наречено Сатана, защото той кривна от правилния път, и Шеда, защото беше изгонен, и Дайуа, защото загуби божествените си одежди. И от това време до ден-днешен той и неговите воини са съблечени от одеждите си и ходят голи и имат ужасяващи лица”. 
Изводът е, че мотивът се е разпространявал в два варианта:

1) с обяснението на Сатанаил, че няма да се поклони на Адам, защото - като създаден преди човека - е по-висш от него (Слово за Авадон, латинската и ориенталските версии на Мъчението на св. Георги);

2) че Сатанаил има огнена природа и не желае да се поклони на създадения от кал човек (Пещерата на съкровищата, Откровение на Варух, славянската версия на Мбчението).

Ясно е обаче, че в първоначалния текст на Мбчението (или в някоя от ранните му преработки) е можело да има един-единствен вариант. Трудно е да се каже кой от двата е бил използван от анонимния агиограф, както и това, кога и защо в един от клоновете на ръкописната традиция той е бил заменен от другия. Със сигурност може да се допусне, че мотивът е възникнал в древноеврейска среда във връзка с ранната библейска екзегеза и чрез старозаветните псевдоепиграфи е преминал във византийската и в други източнохристиянски литератури. Краткият преглед на паралелите, които този мотив има в други - славянски и чуждоезични - съчинения показва, че или анонимният автор на Мбчението е заимствал от някой от споменатите псевдоепиграфи, или, което е най-вероятно, е споделил общ източник с тях. Вариантът на мотива, засвидетелстван в славянските редакции на Мъчението и съдържащ като причина за отказа огнената природа на Сатанаил и презряната същност на човека, направен от пръст, е близък до вариантите, представени в Откровение на Варух и сирийската Пещера на съкровищата, които имат много архаичен характер. Изглежда възможно, съгласно с принципа, че по-трудното четене е вярното, именно запазеният в славянското Мъчение вариант да е бил първоначалният, тъй като в другите - латински, коптски и етиопски - варианти причината за отказа е опростена - там се изтъква просто висшестоящата позиция на архангела пред сътворения (по-късно) човек. Замяната на на първия вариант с втория вероятно е станала на много ранен етап от развитието на текста, още при битуването му в Палестина или на Синай. Но независимо от това, дали наистина е така, тази малка особеност на славянската версия на Мъчението, засвидетелствана и в други (славянски и чуждоезични) произведения, отново потвърждават важността на славянските преводи за реконструирането на историята на даден текст. Освен това, тя също така е свидетелство за характера на ранната християнска агиография, в която наравно с каноничните се включват апокрифни източници. 


\section{БИБЛИОГРАФИЯ}

Димитрова, Д. (1986). Темата за произхода на злото в старобългарската апокрифна проза. In С. Илиев, С. Хаджикосев, \& Й. Найденова (Eds.), Литература, общество, идеи (рр. 25-47). София: БАН.

Димитрова, Д. (2014). Сказание за Тивериадското море: Текстологическо изследване и критическо издание. София: ИЦ Боян Пенев. (Studia medievalia Slavica et Byzantina, 4)

Иванов, Й. (1925). Богомилски книги и легенди. София: Придворна печатница.

Иванов, Й. (1935). Старобългарски разкази. София: Придворна печатница.

Петканова, Д. (1981). Стара българска литература (Vol. 1, Апокрифи). София: Български писател.

Порфирьев, И. Я. (1872). Апокрифические сказания о ветхозаветных лицах и событиях. Казань: Унив. типография.

Стойкова, А., Христова-Шомова, И., Малчев, Р., \& Рангочев, К. (2012). Св. Георги Победоносец. In Encyclopaedia Slavica Sanctorum. Retrieved 11 February 2015, from http:// eslavsanct.net/viewobject.php?id=2374

Тихонравов, Н. С. (1894). Откровение Варуха. In Н. С. Тихонравов, Апокрифические сказания (рp. 48-54). Санкт Петербург. (Сборник Отделения русского языка и словесности, 58(4))

Anderson, G. A. (2000). The exaltation of Adam and the fall of Satan. In G. A. Anderson, M. E. Stone, \& J. Tromp (Eds.), Literature on Adam and Eve: Collected essays (pp. 83-110). Leiden: Brill.

Arndt, W. (1874). Passio Sancti Georgii. Berichte über die Verhandlungen der königlichen sächsischen Gesellschaft der Wissenschaften Leipzig. Philologisch-Historische Classe, 26, 43-70.

Badalanova Geller, F. (2011). The Sea of Tiberias: Between apocryphal literature and oral tradition. In L. DiTommaso, C. Bötrich with M. Swoboda (Eds.), The Old Testament apocrypha in the Slavonic tradition: Continuity and diversity (pp. 13-158). Tübingen: Mohr Siebeck.

Gaylord, H. E. (1982). How Sataniel lost his ,-el'. Journal for Jewish Studies, 33(1-2), 303-309. http://dx.doi.org/10.18647/1049/JJS-1982

Gaylord, H. E. (1983). Jr. 3 (Greek Apocalypse of) Baruch (First to third century A. D.): A new translation and introduction. In J. H. Charlesworth (Ed.), The Old Testament pseudoepigrapha (Vol. 1, Apocalyptic literature and testaments). Garden City, New York: Doubleday.

Johnson, M. D. (1985). Life of Adam and Eve: New translation and introduction. In J.H. Charlesworth (Ed.), The Old Testament pseudoepigrapha (Vol. 2, Expansions of the „Old Testament“ and legends, wisdom and philosophical literature, prayers, psalms and odes). Garden City, New York: Doubleday.

Krumbacher, K. (1911). Der heilige Georg in der griechischen Überlieferung. (A. Ehrhard, Ed.). München: Verlag der Königlich Bayerischen Akademie der Wissenschaften.

Kulik, A. (2010). 3 Baruch. Greek-Slavonic Apocalypse of Baruch. Berlin: De Gruyter. http:// dx.doi.org/10.1515/9783110212495

Novaković, S. (1876). Apokrifi jednoga srpskog ćirilovskog zbornika XIV. vieka. Starine, 8, 74-92.

Stone, M.E. (2000). The fall of Satan and Adam's penance. In G. A. Anderson, M. E. Stone, \& J. Tromp (Eds.), Literature on Adam and Eve: Collected essays (pp. 43-56). Leiden: Brill. 
The Book of the Cave of Treasures. (1927). (E. A. Wallis Budge, Trans. from the Syriac). London: The Religious Tract Society.

Wallis Budge, E. A. (1888). The martyrdom and miracles of Saint George of Cappadocia: The Copitic texts: Ed. with English translation. London: D. Nutt.

Wallis Budge, E. A. (1914). Coptic martyrdoms, etc. in the dialect of Upper Egypt: Ed. with English translation (Vol. 1). London: British Museum.

Wallis Budge, E. A. (1930). George of Lydda, patron saint of England. London: Luzac \& Co.

\section{BIBLIOGRAPHY}

\section{(TRANSLITERATION)}

Anderson, G. A. (2000). The exaltation of Adam and the fall of Satan. In G. A. Anderson, M. E. Stone, \& J. Tromp (Eds.), Literature on Adam and Eve: Collected essays (pp. 83-110). Leiden: Brill.

Arndt, W. (1874). Passio Sancti Georgii. Berichte über die Verhandlungen der königlichen sächsischen Gesellschaft der Wissenschaften Leipzig. Philologisch-Historische Classe, 26, 43-70.

Badalanova Geller, F. (2011). The Sea of Tiberias: Between apocryphal literature and oral tradition. In L. DiTommaso, C. Bötrich with M. Swoboda (Eds.), The Old Testament apocrypha in the Slavonic tradition: Continuity and diversity (pp. 13-158). Tübingen: Mohr Siebeck.

Dimitrova, D. (1986). Temata za proizkhoda na zloto v starobŭlgarskata apokrifna proza. In S. Iliev, S. Khadzhikosev, \& Ĭ. Naĭdenova (Eds.), Literatura, obshtestvo, idei (pp. 25-47). Sofiia: BAN.

Dimitrova, D. (2014). Skazanie za Tiveriadskoto more: Tekstologichesko izsledvane i kritichesko izdanie. Sofiia: ITS Boian Penev. (Studia medievalia Slavica et Byzantina, 4)

Gaylord, H. E. (1982). How Sataniel lost his '-el'. Journal for Jewish Studies, 33(1-2), 303-309. http://dx.doi.org/10.18647/1049/JJS-1982

Gaylord, H. E. (1983). Jr. 3 (Greek Apocalypse of) Baruch (First to third century A. D.): A new translation and introduction. In J. H. Charlesworth (Ed.), The Old Testament pseudoepigrapha (Vol. 1, Apocalyptic literature and testaments). Garden City, New York: Doubleday.

Ivanov, Ĭ. (1925). Bogomilski knigi i legendi. Sofiia: Pridvorna pechatnitsa.

Ivanov, Ĭ. (1935). Starobŭlgarski razkazi. Sofiia: Pridvorna pechatnitsa.

Johnson, M. D. (1985). Life of Adam and Eve: New translation and introduction. In J. H. Charlesworth (Ed.), The Old Testament pseudoepigrapha (Vol. 2, Expansions of the "Old Testament" and legends, wisdom and philosophical literature, prayers, psalms and odes). Garden City, New York: Doubleday.

Krumbacher, K. (1911). Der heilige Georg in der griechischen Überlieferung. (A. Ehrhard, Ed.). München: Verlag der Königlich Bayerischen Akademie der Wissenschaften. 
Kulik, A. (2010). 3 Baruch. Greek-Slavonic Apocalypse of Baruch. Berlin: De Gruyter. http:// dx.doi.org/10.1515/9783110212495

Novaković, S. (1876). Apokrifi jednoga srpskog ćirilovskog zbornika XIV. vieka. Starine, 8, 74-92.

Petkanova, D. (1981). Stara bŭlgarska literatura (Vol. 1, Apokrifi). Sofiia: Bŭlgarski pisatel.

Porfir'ev, I. I. (1872). Apokrificheskie skazaniia o vetkhozavetnykh litsakh i sobytiiakh. Kazan': Univ. tipografiia.

Stoŭkova, A., Khristova-Shomova, I., Malchev, R., \& Rangochev, K. (2012). Sv. Georgi Pobedonosets. In Encyclopaedia Slavica Sanctorum. Retrieved 11 February 2015, from http:// eslavsanct.net/viewobject.php?id=2374

Stone, M. E. (2000). The fall of Satan and Adam's penance. In G. A. Anderson, M. E. Stone, \& J. Tromp (Eds.), Literature on Adam and Eve: Collected essays (pp. 43-56). Leiden: Brill.

The Book of the Cave of Treasures. (1927). (E. A. Wallis Budge, Trans. from the Syriac). London: The Religious Tract Society.

Tikhonravov, N. S. (1894). Otkrovenie Varukha. In N. S. Tikhonravov, Apokrificheskie skazaniia (pp. 48-54). Sankt Peterburg. (Sbornik Otdeleniia russkogo iazyka i slovesnosti, 58(4))

Wallis Budge, E. A. (1888). The martyrdom and miracles of Saint George of Cappadocia: The Copitic texts: Ed. with English translation. London: D. Nutt.

Wallis Budge, E. A. (1914). Coptic martyrdoms, etc. in the dialect of Upper Egypt: Ed. with English translation (Vol. 1). London: British Museum.

Wallis Budge, E. A. (1930). George of Lydda, patron saint of England. London: Luzac \& Co.

\section{O możliwych źródłach apokryficznego motywu „Satanael odmawia złożenia hołdu Adamowi” w pewnej wczesnochrześcijańskiej pasji}

W artykule przedstawiono średniowieczne dzieła literackie, zawierające jeden z wariantów motywu apokryficznego - upadek z nieba zbuntowanego anioła, w którym Satanael nazywa siebie samego "płomieniem ognia” i odmawia złożenia hołdu stworzonemu z błota Adamowi. Wariant tego motywu został odkryty w słowiańskiej wersji wczesnochrześcijańskiej Pasji św. Jerzego (anonimowego autora), podczas gdy wersje łacińska, koptyjska i etiopska przedstawiają ten wątek w sposób dalece uproszczony - powodem odmowy anioła jest jego wyższa pozycja w stosunku do człowieka. Wydaje się prawdopodobne, że słowiańska wersja zachowała oryginalny wariant motywu, występujący w tej samej formie tylko w dwóch jeszcze pracach - grecko-słowiańskiej Apokalipsie Barucha (3 Baruch) i syryjskiej Grocie Skarbów, obu mających cechy archaiczne, podczas gdy w wersji łacińskiej i orientalnych widoczne są już zmiany. Jeśli faktycznie tak jest, to zastąpienie wcześniejszej wersji musiało nastąpić na wczesnym stadium rozwoju tekstu, prawdopodobnie już w czasie cyrkulowania Pasji w Palestynie lub na Synaju.

Słowa kluczowe: Stary Testament, apokryf, Satanael, Adam, słowiańska Pasja św. Jerzego 


\section{On the Possible Sources of the Apocryphal Motif "Satanael Refuses to Bow to Adam" in One Early Christian Passion}

The article discusses the medieval literary works containing one of the variants of the apocryphal motif "the fall of the Rebel Angel from Heaven," where Satanael calls himself "a fire flame" and refuses to bow to Adam, who was created "from mud." A variant of this motif is found in the Slavonic version of an early anonymous Passion of St. George, while its Latin, Coptic and Ethiopian versions contain a more simplified variant - the reason for the refusal of the angel is his superior position in comparison to man. It seems possible that the Slavonic version preserved the original variant of the motif, known in the same form in only two more works - the Greek-Slavonic Apocalypse of Baruch (3 Baruch) and the Syriac Cave of Treasures, both of which preserved archaic features, whereas the Latin and the Oriental versions show traces of later changes. If this is indeed the case, the replacement of the earlier version occurred at a very early stage of the development of the text, probably already during the circulation of the Passion in Palestine or in Sinai.

Keywords: Old Testament apocrypha, Satanael, Adam, Slavonic Passion of St. George

\section{Notka o autorze}

Ana Stoykova (Ана Стойкова) (ana.stoykova@gmail.com) - doktor habilitowana, docent $w$ Instytucie Literatury Bułgarskiej Akademii Nauk, redaktor naczelna serii wydawniczej „Starobalgarska literatura”. Autorka książek: Физиологът в южнославянските литератури (1994), Първоучителят Методий (1995), wydania elektronicznego The Slavic Physiologus of the Byzantine Recension: Electronic Text Edition and Comparative Study (2011). Zainteresowania naukowe: średniowieczne literatury słowiańskie, tradycja cyrylometodejska, hagiologia i hagiografia, cyfrowe metody badań średniowiecznych manuskryptów słowiańskich.

Ana Stoykova, $\mathrm{PhD}$ (ana.stoykova@gmail.com) - Associate Professor at the Institute for Literature, Bulgarian Academy of Sciences. Editor-in-chief of the journal "Starobalgarska literatura." Author of the books: Fiziologat v yuzhnoslavyanskite literaturi (1994), Parvouchitelyat Metodiy (1995), The Slavic Physiologus of the Byzantine Recension: Electronic Text Edition and Comparative Study (2011). Research interests: medieval Slavic literatures, Cyrillo-Methodian traditions, hagiology and hagiography, and computer assisted methods in studying of medieval Slavic manuscripts. 